\title{
FAKTOR-FAKTOR YANG BERHUBUNGAN DENGAN KEJADIAN NYERI MENSTRUASI (DISMINORE) PADA REMAJA PUTRI
}

\author{
Dina Permata Sari ${ }^{1}$, Titin Dewi Sartika ${ }^{2}$,Erma Puspitasari ${ }^{3}$, Chairuna ${ }^{4}$ \\ Mahasiswa Universitas Kader Bangsa Palembang ${ }^{1}$, Dosen Universitas Kader Bangsa Palembang ${ }^{234}$ \\ Email: 'dinapermatasari959@gmail.com, ${ }^{2}$ titin_dewi@yahoo.com, ${ }^{3}$ ermapuspitasari88@gmail.com
}

\begin{abstract}
Menstruation is endometrium releasing process included with bleeding and happened many times every month except in pregnancy. According to the World Health Organization (WHO) the number of disminore in the world is very large, the average more than $50 \%$ of women in every country suffer from disminore. The aims of this research is to find out the correlation of menarche age, length of menstruation and family history with menstrual pain incident to the teenage girl of Social Class XI of Islamic Senior High School Number 1 year 2021. The method of this research used Survey Analitic with Cross Sectional approach. The populations in this research are all schoolgirls of Class XI of Islamic Senior High School Number 1 Palembang year 2021/2022, which amount 168 pepole. Big samples of this research are 63 respondents whom taken from using Stratified random sampling. Data collecting used questioner sheet. Data analysis used univariate and bivariate by using chi square test. Results : respondents who experience menstruation pain are 35 (55,6\%) teenagers, normal menarche age respondents are $45(71,4 \%)$ teenagers, respondents who experience normal menstruation length are 50 (79,4\%) teenagers, respondents who have no disminore experiences family history are $42(66,7 \%)$ teenagers. Bivariate result known that there is menarche age (length of menstruation) and family history (with menstruation pain incident to the teenage girls of Class XI of Islamic Senior High School Number 1 year 2021. The conclusion that there is correlation between menarche age, length of menstruation and family history with menstruation pain incident to the teenage girls of Social Class XI of Islamic Senior High School Number 1 year 2021. Suggestion : expected to the school authorities to cooperate with Health agencies to give counseling to the schoolgirls about female reproduction especially disminore.
\end{abstract}

Keywords : Menstrual Pain, Age of Menarche, Length of Menstruation, Family History

\begin{abstract}
ABSTRAK
Menstruasi merupakan proses pelepasan dinding rahim (endometrium) yang disertai dengan perdarahan dan terjadi secara berulang setiap bulan kecuali pada saat kehamilan. Berdasarkan Badan Kesehatan Dunia (WHO) angka disminore di dunia sangat besar, rata-rata lebih dari $50 \%$ perempuan di setiap negara mengalami disminore. Tujuan penelitian untuk mengetahui hubungan usia menarche, lama menstruasi dan riwayat keluarga dengan kejadian nyeri menstruasi pada remaja putri kelas XI IPS MAN 1 tahun 2021. Metode penelitian menggunakan Survey Analitik dengan pendekatan Cross Sectional. Populasi dalam penelitian adalah semua siswi kelas XI MAN 1 Palembang tahun ajaran 2021/2022, yang berjumlah 168 orang. Besar sampel penelitian ini menggunakan rumus Slovin sebanyak 63 responden yang diambil dengan menggunakan teknik stratified random sampling. Pengumpulan data menggunakan lembar kuesioner. Analisa data menggunakan analisa univariat dan analisa bivariat dengan menggunakan uji chi square. Hasil penelitian ini didapatkan responden yang mengalami nyeri menstruasi sebanyak $35(55,6 \%)$ remaja, responden usia menarche normal sebanyak $45(71,4 \%)$ remaja, responden yang mengalami lama menstruasi normal sebanyak 50 (79,4\%) remaja, responden tidak memiliki riwayat keluarga mengalami disminroe sebanyak $42(66,7 \%)$ remaja. Hasil bivariat diketahui ada hubungan usia menarche ( $p$ value $=0,049)$, lama menstruasi $(p$ value $=0,040)$ dan riwayat keluarga $(p$ value $=0,039)$ dengan kejadian nyeri menstruasi pada remaja putri kelas XI MAN 1 tahun 2021. Kesimpulan ada hubungan usia menarche, lama menstruasi dan riwayat keluarga dengan kejadian nyeri menstruasi pada remaja putri kelas XI IPS MAN 1 tahun 2021. Saran: diharapkan kepada pihak sekolah untuk bekerja sama dengan instansi kesehatan untuk memberikan penyuluhan kepada siswi mengenai reproduksi wanita khususnya disminore.
\end{abstract}

Kata kunci: Nyeri Menstruasi, Usia Menarche, Lama Menstruasi, Riwayat Keluarga 


\section{PENDAHULUAN}

Menstruasi merupakan proses pelepasan dinding rahim (endometrium) yang disertai dengan perdarahan dan terjadi secara berulang setiap bulan kecuali pada saat kehamilan (Haryono, 2016). Bagi beberapa orang menstruasi menjadi hal yang biasa-biasa saja namun bagi sebagian wanita tidak demikian adanya. Berbagai macam gangguan muncul beberapa hari menjelang menstruasi atau saat menstruasi berlangsung. Salah satunya yaitu nyeri pada saat menstruasi yang disebabkan oleh kejang otot uterus atau biasa disebut dengan istilah disminore (Mitayani dalam Siagian, 2015).

Hal ini sangat wajar dialami separuh perempuan, namun sekitar $10 \%$ perempuan mengalami rasa sakit yang hebat hingga perlu meminum obat pereda nyeri haid untuk mengurangi rasa sakit (Haryono, 2016).

Berdasarkan Badan Kesehatan Dunia (WHO) angka disminore di dunia sangat besar, rata-rata lebih dari $50 \%$ perempuan di setiap negara mengalami disminore. Di Swedia sekitar 72\%. Di Amerika Serikat diperkirakan hampir 90\% wanita mengalami disminore, dan $10-15 \%$ diantaranya mengalami disminore berat, yang menyebabkan mereka tidak mampu melakukan kegiatan apapun. Di Indonesia sendiri kejadian disminore cukup besar, menunjukkan penderita disminore mencapai $60-70 \%$ wanita di Indonesia. Angka kejadian dimenore tipe primer di Indonesia adalah $54,89 \%$,sedangkan sisanya $45,11 \%$ adalah tipe sekunder (Lail, 2019).

Penelitian Yulita (2019) sebagian besar siswi SMA Negeri Purwodadi Sumatera Selatan mengalami nyeri disminore sedang sebanyak 33 siswi (68,8\%) (Febrina, 2021). Data dinkes Kota Palembang tahun (2015) yang mengalami nyeri saat menstruasi sebesar 64,3\% (Dewi, 2016).

Berdasarkan studi pendahuluan peneliti di MAN 1 kelas XI terdiri dari 168 siswi. Dari hasil wawancara yang dilakukan peneliti pada 20 siswi kelas XI MAN 1 Palembang diketahui bahwa sebanyak 14 siswi mengalami disminore setiap menstruasi sedangkan 6 siswi tidak mengalami disminore.

Rasa sakit yang ditimbulkan oleh dismenorhea akan mempengaruhi secara emosional dan fisik siswi sehingga diperlukan suatu tindakan atau pencegahan untuk mengatasi rasa sakit saat menstruasi ini. Dismenorhea juga sering menjadi alasan seorang siswi untuk tidak masuk mengikuti perkuliahan sehingga akan menganggu prestasi belajar (Masnilawati, 2018).

Penyebab terjadinya disminore primer belum semuanya dapat diketahui, namun ada beberapa faktor yang dihubungkan terjadinya disminore yaitu umur, usia menarche lebih dini, riwayat keluarga, lama menstruasi. Pada wanita dengan disminore primer, maka ketika saat menstruasi, pada endometrium fasesekresi memproduksi prostaglandin yang menyebabkan kontraksi otot-otot polos. Jika produksi prostaglandin berlebihan maka akan dapat mengakibatkan kram pada otot-otot uterus, kemudian dapat menyebabkan iskemik sehingga terjadi disminore atau nyeri menstruasi, wanita disminore menghasilkan 8-13 kali lebih banyak prostaglandin $\mathrm{F}$ dibandingkan dengan wanita yang tidak mengalami nyeri menstruasi (Silaban, 2019).

Menarche pada usia lebih awal menyebabkan alat-alat reproduksi belum berfungsi secara optimal dan belum siap mengalami perubahan-perubahan sehingga timbul nyeri ketika menstruasi. Menarche atau menstruasi pertama pada umumnya dialami remaja pada usia 13-14 tahun, namun pada beberapa kasus dapat terjadi pada usia $\leq 12$ tahun. Menarche yang terjadi pada usia yang lebih awal dari normal, dimana alat reproduksi belum siap untuk mengalami perubahan dan masih terjadi penyempitan pada leher rahim, maka akan timbul rasa sakit ketika menstruasi (Lubis, 2018).

Hasil penelitian Ariani (2018) dengan judul hubungan antara usia menarche dengan kejadian disminore primer pada remaja putrikelas VIII di SMP Negeri 9 Banjarmasin. Hasil penelitian menunjukkan bahwa ada hubungan yang bermakna antara usia menarche dengan kejadian disminore primer ( $p$ value $=0,027$ ).

Lama menstruasi dapat disebabkan oleh faktor psikologis maupun fisiologis. Secara psikologis biasanya berkaitan dengan tingkat emosional remaja putri yang labil ketika baru mengalami menstruasi. Sementara secara fisiologis lebih kepada terjadinya kontraksi otot uterus yang berlebihan atau dapat dikatakan mereka sangat sensitif terhadap hormon ini akibat endometrium dalam fase sekresi memproduksi hormon prostaglandin. Prostagladin terbentuk dari asam lemak tak jenuh yang disintesis oleh seluruh sel yang ada dalam tubuh. Hal ini menyebabkan kontraksi otot polos yang akhirnya menimbulkan rasa nyeri (Angelina, 2017). 
Hasil penelitian Sadiman (2017) dengan judul faktor-faktor yang berhubungan dengan kejadian dismenorhea. Hasil penelitian menunjukkan ada hubungan antara lama menstruasi ( $\mathrm{p}$ value $=0,032$ ) dengan kejadian disminore.

Wanita yang memiliki riwayat disminore primer pada keluarganya memiliki prevalensi yang lebih besar untuk terjadinya disminore primer. Beberapa peneliti memperkirakan anak dari ibu yang memiliki masalah menstruasi juga mengalami menstruasi yang tidak menyenangkan, ini merupakan alasan yang dapat dihubungkan terhadap tingkah laku yang dipelajari dari ibu. Alasan riwayat keluarga merupakan faktor risiko disminore primer mungkin dihubungkan dengan kondisi seperti endometriosis (Ozerdogan dalam Hayati, 2020). Menurut Wiknjosastro (2015) mengemukakan bahwa adanya riwayat keluarga dan genetik berkaitan dengan terjadinya disminore primer yang berat.

Hasil penelitian Romlah (2020) dengan judul faktor-faktor yang berhubungan dengan kejadian disminore pada siswa kelas XI di SMK Sasmita Jaya 1 Pamulang menunjukkan terdapat hubungan menarche $(\mathrm{p}$ value $=0,025)$ dan riwayat keluarga ( $\mathrm{p}$ value $=0,002)$ dengan kejadian disminore. Begitu juga dengan penelitian Nurwana (2016) dengan judul faktor Yang Berhubungan Dengan Kejadian Disminorea Pada Remaja Putri Di SMA Negeri 8 Kendari. Hasil analisis menunjukkan bahwa ada hubungan yang signifikan antara menarche pada usia awal ( $\mathrm{p}$ value $=0,047$ ), lama menstruasi ( $\mathrm{p}$ value $=0,043)$,

Tabel 1 Distribusi Frekuensi Variabel Penelitian status gizi ( $\mathrm{p}$ value $=0,037$ ) dengan kejadian disminore.

Berdasarkan uraian di atas, maka penulis tertarik untuk melakukan penelitian mengenai "Faktor-faktor yang berhubungan dengan kejadian nyeri menstruasi pada remaja putri di kelas XI MAN 1 Palembang tahun 2021”.

\section{Tujuan}

Untuk mengetahui hubungan usia menarche, lama menstruasi dan riwayat keluarga secara simultan dengan kejadian nyeri menstruasi pada remaja putri kelas XI IPS MAN 1 tahun 2021.

\section{METODE PENELITIAN}

Desain penelitian bersifat kuantitatif dengan menggunakan survey analitik dengan pendekatan cross sectional. Penelitian ini dilaksanakan di MAN 1 Palembang pada bulan Agustus 2021. Populasi dalam penelitian ini adalah semua siswi kelas XI MAN 1 Palembang tahun ajaran 2021/2022, yang berjumlah 168 orang. Besar sampel pada penelitian ini menggunakan rumus slovin sehingga didapatkan 63 responden diambil dengan teknik stratified random sampling. Instrumen penelitian berupa lembar kuesioner. Analisa data menggunakan analisa univariat dan analisa bivariat dengan uji statistik chi square.

\section{HASIL PENELITIAN \\ Hasil Univariat}

\begin{tabular}{clcc}
\hline & Nyeri menstruasi & Frekuensi & $\begin{array}{c}\text { Persentase } \\
(\mathbf{\%})\end{array}$ \\
\hline 1 & Ya & 35 & 55,6 \\
2 & Tidak & 28 & 44,4 \\
& Usia Menarche & Frekuensi & Persentase (\%) \\
\hline 1 & Menarche Dini & 18 & 28,6 \\
2 & Normal & 45 & 71,4 \\
& Lama Menstruasi & Frekuensi & Persentase (\%) \\
\hline 1 & Tidak normal & 13 & 20,6 \\
2 & Normal & 50 & 79,4 \\
\hline \multicolumn{2}{r}{ Riwayat Keluarga } & $\mathbf{f}$ & $\mathbf{\%}$ \\
\hline 1 & Ya & 21 & 33,3 \\
\hline 2 & Tidak & 42 & 66,7 \\
\hline \multicolumn{2}{r}{ Jumlah } & $\mathbf{6 3}$ & $\mathbf{1 0 0}$ \\
\hline
\end{tabular}


Tabel 2 Hubungan variabel Independen dengan variabel Dependen

\begin{tabular}{|c|c|c|c|c|c|c|c|c|c|}
\hline \multirow{3}{*}{ No } & \multirow{3}{*}{ Variabel } & \multicolumn{4}{|c|}{ Nyeri Menstruasi } & \multirow{2}{*}{\multicolumn{2}{|c|}{ Total }} & \multirow{3}{*}{ p value } & \multirow{3}{*}{ OR } \\
\hline & & \multicolumn{2}{|c|}{ Ya } & \multicolumn{2}{|c|}{ Tidak } & & & & \\
\hline & & $\mathbf{n}$ & $\%$ & $\mathbf{n}$ & $\%$ & $\mathbf{n}$ & $\%$ & & \\
\hline & \multicolumn{9}{|l|}{ Usia Menarche } \\
\hline $\mathbf{1}$ & Menarche dini & 14 & 77,8 & 4 & 22,2 & 18 & 100 & \multirow{3}{*}{0,049} & \multirow{3}{*}{4} \\
\hline & Normal & 21 & 46,7 & 24 & 53,3 & 45 & 100 & & \\
\hline & Jumlah & 35 & & 28 & & 63 & 100 & & \\
\hline \multirow[t]{4}{*}{2} & Lama Menstruasi & & & & & & & \multirow{4}{*}{0,040} & \multirow{4}{*}{5,958} \\
\hline & Tidak normal & 11 & 84,6 & 2 & 15,4 & 13 & 100 & & \\
\hline & Normal & 24 & 48 & 26 & 52 & 50 & 100 & & \\
\hline & Jumlah & 35 & & 28 & & 63 & 100 & & \\
\hline \multirow[t]{4}{*}{3} & Riwayat Keluarga & & & & & & & \multirow{4}{*}{0,039} & \multirow{4}{*}{3,874} \\
\hline & $\mathrm{Ya}$ & 16 & 76,2 & 5 & 23,8 & 21 & 100 & & \\
\hline & Tidak & 19 & 45,2 & 23 & 54,8 & 42 & 100 & & \\
\hline & Jumlah & 35 & & 28 & & 63 & 100 & & \\
\hline
\end{tabular}

\section{Pembahasan}

\section{Kejadian Nyeri Menstruasi pada Remaja}

Hasil penelitian menunjukkan lebih dari separoh yang mengalami nyeri menstruasi sebanyak $35(55,6 \%)$ remaja.

Menurut Haryono (2016), nyeri haid yang sering dialami pada saat hari pertama menstruasi dan berlangsung 2-3 hari. Rasa sakit bagian bawah perut bagian bawah tetapi dapat menyebar hingga ke punggung bawah dan paha. Hal ini sangat wajar dialami separuh perempuan, namun sekitar $10 \%$ perempuan mengalami rasa sakit yang hebat hingga perlu meminum obat pereda nyeri haid untuk mengurangi rasa sakit.

Menurut Silaban (2019), penyebab terjadinya disminore primer belum semuanya dapat diketahui, namun ada beberapa faktor yang dihubungkan terjadinya disminore yaitu umur, usia menarche lebih dini, riwayat keluarga, lama menstruasi.

Penelitian ini sejalan dengan hasil penelitian Yulita (2019) sebagian besar siswi SMA Negeri Purwodadi Sumatera Selatan mengalami nyeri disminore sedang sebanyak 33 siswi $(68,8 \%)$
Berdasarkan hasil penelitian, teori dan penelitian terkait peneliti berasumsi bahwa nyeri haid yang sering dialami pada saat hari pertama menstruasi dan berlangsung 2-3. Penyebab terjadinya disminore primer belum semuanya dapat diketahui, namun ada beberapa faktor yang dihubungkan terjadinya disminore yaitu umur, usia menarche lebih dini, riwayat keluarga, lama menstruasi

2. Hubungan Usia Menarche dengan Nyeri Menstruasi (Disminore)

Hasil penelitian menunjukkan sebagian besar mengalami usia menarche normal sebanyak $45(71,4 \%)$ remaja.

Hasil uji statistik Chi-Square pada tingkat kemaknaan $\alpha=0,05$ diperoleh nilai $p$ value $=0,049$ yang berarti ada hubungan usia menarche dengan nyeri menstruasi. Hasil Odds Ratio diperoleh nilai 4 yang berarti bahwa usia menarche dini berpeluang 4 kali lebih besar mengalami nyeri menstruasi dibandingkan dengan usia menarche normal.

Sejalan dengan teori Lubis (2018) menarche pada usia lebih awal menyebabkan alat-alat reproduksi belum berfungsi secara optimal dan belum siap mengalami perubahan-perubahan sehingga timbul nyeri 
ketika menstruasi. Menarche atau menstruasi pertama pada umumnya dialami remaja pada usia 13-14 tahun, namun pada beberapa kasus dapat terjadi pada usia $\leq 12$ tahun. Menarche yang terjadi pada usia yang lebih awal dari normal, dimana alat reproduksi belum siap untuk mengalami perubahan dan masih terjadi penyempitan pada leher rahim, maka akan timbul rasa sakit ketika menstruasi.

Hal ini sejalan dengan penelitian Ariani (2018) dengan judul hubungan antara usia menarche dengan kejadian disminore primer pada remaja putrikelas VIII di SMP Negeri 9 Banjarmasin. Hasil penelitian menunjukkan bahwa ada hubungan yang bermakna antara usia menarche dengan kejadian disminore primer ( $p$ value $=0,027$ ).

Penelitian ini sejalan hasil penelitian Aditiara (2018) dengan judul hubungan antara usia menarche dengan dysmenorrhea primer pada mahasiswa keperawatan S1 angkatan 2015 di Universitas Muhammadiyah Surakarta. Hasil penelitian ada hubungan antara usia menarche dengan dysmenorrhea primer pada mahasiswa keperawatan S1 angkatan 2015 Universitas Muhammadiyah Surakarta $(\mathrm{p}=0,041)$

Berdasarkan hasil penelitian, teori dan penelitian terkait peneliti berasumsi bahwa usia menarche merupakan salah satu faktor yang menyebabkan responden mengalami disminore karena usia menarche dini yang terjadi pada usia yang lebih awal dari normal, dimana alat reproduksi belum siap untuk mengalami perubahan dan masih terjadi penyempitan pada leher rahim, maka akan timbul rasa sakit ketika menstruasi.

3. Hubungan Lama Menstruasi dengan Nyeri Menstruasi (Disminore)

Hasil penelitian menunjukkan sebagian besar mengalami lama menstruasi normal sebanyak $50(79,4 \%)$ remaja.

Hasil uji statistik Chi-Square pada tingkat kemaknaan $\alpha=0,05$ diperoleh nilai $p$ value $=0,040$ yang berarti ada hubungan lama menstruasi dengan nyeri menstruasi. Hasil Odds Ratio diperoleh nilai 5,958 yang berarti bahwa lama menstruasi tidak normal berpeluang 5,958 kali lebih besar mengalami nyeri menstruasi dibandingkan dengan lama menstruasi normal.

Sejalan dengan teori menurut Sadiman (2017) menstruasi yang lebih lama menyebabkan nyeri kemungkinan karena pada responden dengan lama menstruasi lebih dari 7 hari akan kehilangan darah lebih banyak dari pada responden dengan lama menstruasi yang singkat. Remaja dengan menstruasi lebih lama berisiko menderita disminore apabila kebutuhan akan zat besi yang berasal dari zat makanan dan tablet Fe tidak terpenuhi. Selain itu semakin lama menstruasi terjadi, maka semakin sering uterus berkontraksi, akibatnya semakin banyak pula prostaglandin yang dikeluarkan. Akibat prostaglandin yang berlebihan makan timbul rasa nyeri pada saat menstruasi. Untuk mencegah terjadinya lamanya mentruasi dengan pemenuhan gizi seimbang, memberikan tablet $\mathrm{Fe}$ pada remaja putri yang sudah mengalami menstruasi khususnya yang mengalami lama menstruasi lebih dari 7 hari dan diharapkan para guru menganjurkan para siswi mengkonsumsi nutrisi seimbang seperti karbohidrat, protein, vitamin dan mineral seperti zat besi agar kebutuhan zat besi terpenuhi untuk pembentukan sel-sel darah merah. Selain itu menerapkan kebiasaan hidup sehat sehari-hari seperti berolahraga juga dapat membantu mengurangi terjadinya disminore.

Hasil penelitian ini sejalan dengan penelitian Nurwana (2016) dengan judul faktor Yang Berhubungan Dengan Kejadian Disminorea Pada Remaja Putri Di SMA Negeri 8 Kendari. Hasil analisis menunjukkan bahwa ada hubungan yang signifikan antara menarche pada usia awal ( $\mathrm{p}$ value $=0,047$ ), lama menstruasi ( $\mathrm{p}$ value $=0,043$ ), status gizi ( $\mathrm{p}$ value $=0,037)$ dengan kejadian disminore.

Hasil penelitian ini juga sejalan dengan penelitian Sadiman (2017) dengan judul faktor-faktor yang berhubungan dengan kejadian dismenorhea. Hasil penelitian menunjukkan ada hubungan antara lama menstruasi ( $\mathrm{p}$ value $=0,032$ ) dengan kejadian disminore.

Berdasarkan hasil penelitian peneliti berpendapat bahwa lama menstruasi yang lebih dari normal yaitu lebih dari 7 hari dapat menyebabkan disminore karena akan kehilangan darah lebih banyak dan semakin sering uterus berkontaksi, akibatnya semakin banyak pula prostaglandin yang dikeluarkan. Akibat prostaglandin yang berlebihan makan timbul rasa nyeri pada saat menstruasi.

4. Hubungan Riwayat Keluarga dengan Nyeri Menstruasi (Disminore)

Hasil penelitian menunjukkan lebih dari separoh tidak memiliki riwayat keluarga mengalami disminroe yaitu sebanyak 42 $(66,7 \%)$ remaja. 
Hasil uji statistik Chi-Square pada tingkat kemaknaan $\alpha=0,05$ diperoleh nilai $p$ value $=0,039$ yang berarti ada hubungan riwayat keluarga dengan nyeri menstruasi. Hasil Odds Ratio diperoleh nilai 3,874 yang berarti bahwa responden yang memiliki riwayat keluarga disminore berpeluang 3,874 kali lebih besar mengalami nyeri menstruasi dibandingkan dengan yang tidak memiliki riwayat keluarga disminore.

Sejalan dengan teori Ozerdogan dalam Hayati (2020), wanita yang memiliki riwayat disminore primer pada keluarganya memiliki prevalensi yang lebih besar untuk terjadinya disminore primer. Beberapa peneliti memperkirakan anak dari ibu yang memiliki masalah menstruasi juga mengalami menstruasi yang tidak menyenangkan, ini merupakan alasan yang dapat dihubungkan terhadap tingkah laku yang dipelajari dari ibu. Alasan riwayat keluarga merupakan faktor risiko disminore primer mungkin dihubungkan dengan kondisi seperti endometriosis.

Hasil penelitian ini dengan penelitian Romlah (2020) dengan judul faktor-faktor yang berhubungan dengan kejadian disminore pada siswa kelas XI di SMK Sasmita Jaya 1 Pamulang menunjukkan terdapat hubungan menarche $(\mathrm{p}$ value $=0,025)$ dan riwayat keluarga ( $\mathrm{p}$ value $=0,002$ ) dengan kejadian disminore.

Hasil penelitian juga sejalan dengan penelitian Puspita (2017) dengan judul hubungan usia menarche dan riwayat haid keluarga dengan kejadian disminore primer pada remaja putri kelas VIII di SMPN I Gadingrejo Kecamatan Gadingrejo Kabupaten Pringsewu Provinsi Lampung. Hasil penelitian ada hubungan yang signifikan antara riwayat keluarga ( $p$ value 0,001 ) dengan kejadian disminore.

Berdasarkan hasil penelitian peneliti berpendapat bahwa riwayat keluarga (ibu atau saudara perempuan kandung) yang mengalami disminore menyebabkan seorang wanita untuk menderita disminorea parah, hal ini berhubungan karena kondisi anatomis dan fisiologis dari seseorang pada umumnya hampir sama dengan orang tua dan saudarasaudaranya.

\section{KESIMPULAN DAN SARAN \\ Kesimpulan}

1. Ada hubungan usia menarche, lama menstruasi dan riwayat keluarga secara simultan dengan kejadian nyeri menstruasi pada remaja putri kelas XI MAN 1 tahun 2021.

2. Ada hubungan usia menarche secara parsial dengan kejadian nyeri menstruasi pada remaja putri kelas XI MAN 1 tahun 2021 ( $p$ value $=0,049$ ).

3. Ada hubungan lama menstruasi secara parsial dengan kejadian nyeri menstruasi pada remaja putri kelas XI MAN 1 tahun 2021 ( $p$ value $=0,040$ ).

4. Ada riwayat keluarga secara parsial dengan kejadian nyeri menstruasi pada remaja putri kelas XI MAN 1 tahun 2021 ( $p$ value $=0,039$ )

\section{Saran}

\section{Kepada MAN 1 Palembang}

Diharapkan kepada pihak sekolah untuk bekerja sama dengan instansi kesehatan untuk memberikan penyuluhan kepada siswi mengenai reproduksi wanita khususnya disminore.

\section{Kepada Universitas Kader Bangsa} Palembang

Penelitian ini dapat dijadikan sebagai bahan referensi dan menambah kepustakaan dalam melakukan penelitian khususnya yang berhubungan dengan disminore dan diharapkan untuk dapat mengupayakan bukubuku atau jurnal terbaru.

\section{Kepada Peneliti Yang Akan Datang}

Bagi peneliti selanjutnya diharapkan melanjutkan penelitian dengan meneliti faktor-faktor lain penyebab disminore, sehingga dapat memperoleh data yang lebih akurat, serta melakukan metode pengumpulan data dan desain yang berbeda.

\section{DAFTAR PUSTAKA}

Anurogo DA. (2011). Cara Jitu Mengatasi Nyeri Haid. Yogyakarta: Andi Yogyakarta

Fitri I. (2017). Lebih Dekat Dengan Sistem Reproduksi Wanita. Yogyakarta: Gosyen Publishing

Haryono R. (2016). Siap menghadapi Menstruasi dan Menopause. Yogyakarta. Goysen Publishing.

Judha M. (2012). Teori Pengukuran Nyeri dan Nyeri Persalinan. Yogyakarta. Nuha Medika 
Kusmiran E. (2015). Kesehatan Reproduksi Remaja dan Wanita. Jakarta: Salemba Medika

Lumongga LN. (2013). Buku PSIKOLOGI KESPRO Wanita dan Perkembangan Reproduksinya. Cetakan ke-1. Jakarta : Prananda Media Group.

Notoatmodjo S. (2018). Metodelogi Penelitian Kesehatan. Jakarta : Rineka Cipta.

Potter dan Perry. (2015). Buku Ajar Fundamental Keperawatan. Jakarta: EGC.

Profil MAN I Palembang tahun 2021.

Ratnawati A. (2018). Buku Asuhan Keperawatan Pada Pasien Dengan Gangguan Sistem Reproduksi. Yogyakarta : Pustaka Baru Press.

Smeltzer SC dan Bare. BG. (2013). Buku ajar buku keperawatan medikal bedah Jakarta: EGC.

Winarsih S. (2017). Memamahi Kontrasepsi Hormonal Wanita. Yogyakarta. Trans Medika.

Aditiara EB. (2018). Hubungan antara usia menarche dengan dysmenorrhea primer pada mahasiswa keperawatan S1 angkatan 2015 di Universitas Muhammadiyah Surakarta. Jurnal Universitas Muhammadiyah Surakarta. Pp1-10

Angelina. (2017). Faktor yang berhubungan dengan disminore Pada remaja putri di sekolah menengah atas kecamatan sengah Temila kabupaten Landak. Jurnal Mahasiswa dan Penelitian Kesehatan. Vol. 5 No.1 pp 1-10.

Ariani M. (2018). Hubungan antara usia menarche dengan kejadian disminore primer pada remaja putrikelas VIII di SMP Negeri 9 Banjarmasin. Jurnal Kampus STIKes YPIB Majalengka. Vol 7 No. 14pp 81-85

Fadhilah H (2019). Hubungan lama menstruasi dan indeks massa tubuh (IMT) dengan disminore pada remaja putri di MAN 1 Sleman. Jurnal Universitas 'Aisyiyah Yogyakarta.

Fatmawati E. (2020). Hubungan menarche serta riwayat keluarga dengan disminore pada mahasiswi semester II di STIKes Madani Yogyakarta. Jurnal Kesehatan Madani Medika. Vol 11, No 01pp 12-20

Gustina T (2015). Hubungan antara usia menarche dan lama menstruasi dengan kejadian disminore primer pada remaja putri di SMK Negeri 4 Surakarta. Artikel Penelitian Universitas Muhammadiyah Surakarta. Pp 1-14
Hayati S. (2020). Faktor-faktor yang berhubungan dengan kejadian disminore primer di SMA Pemuda Banjaran. Jurnal Keperawatan BSI. Vol 8 No 1. Pp 132-142

Khotimah, H dan Kimantoro. (2014). Pengetahuan Remaja Putri tentang Menstruasi dengan Sikap Menghadapi Dismenore Kelas XI di SMA Muhammadiyah 7 Yogyakarta. Jurnal Ners dan Kebidanan Indonesia. Vol. 2, No. 3, 136-140

Lail HN. (2019). Hubungan Status Gizi, Usia Menarche dengan Disminorea pada Remaja Putri Di SMK K Tahun 2017. Artikel penelitian. Vol.9. No.2 pp 88-95

Lubis YP. (2018). Faktor-Faktor Yang Berhubungan Dengan Kejadian Disminore Primer Pada Remaja Siswi SMA Dharma Sakti Medan. Skripsi Politeknik Kemenkes Medan.

Masnilawati A. (2018). Pengaruh pemberian Vitamin E terhadap perubahan derajat dismenorhea dan kadar prostaglandin pada remaja putri di Kebidanan UMI. Jurnal Sinergitas Multidisiplin Ilmu Pengetahuan dan Teknologi. Vol. 1 pp 30-38

Nurwana (2016). Faktor Yang Berhubungan Dengan Kejadian Disminorea Pada Remaja Putri Di SMA Negeri 8 Kendari. Jurnal Ilmiah Mahasiswa Masyarakat. Vol. 2 No. 6 pp 1-1.

Puspita L (2017). Hubs _ ienarche dan riwayat haid keluarga dengan kejadian disminore primer pada remaja putri kelas VIII di SMPN I Gadingrejo Kecamatan Gadingrejo Kabupaten Pringsewu Provinsi Lampung. Jurnal Kelitbangan Pengembangan dan Inovasi Iptek Kabupaten Pringsewu Volume 2, No 1 pp1-16

Romlah NS. (2020). Faktor-faktor yang berhubungan dengan kejadian disminore pada siswa kelas XI di SMK Sasmita Jaya 1 Pamulang. Jurnal Prosiding Senantias. Vol. 1 No. 1. Pp 383-392

Sadiman S. (2017). Faktor-faktor yang berhubungan dengan kejadian dismenorhea. Jurnal Kesehatan. Vol 8 No 1 pp 41-49

Siagian D. (2015). Perbedaan Tingkat Neri Haid (Disminorea) sebelum dan sesudah senam disminorea. Jurnal. Poltekkes Tanjungkarang. Vol. 11 No.1 pp 123-126

Silaban SDT. (2019). Pengaruh Pemberian Madu Murni Kaliandra Terhadap Perubahan Derajat Dismenorhea pada Remaja Putri di Poltekes Kemenkes Padang. Artikel Penelitian. Vol 8 No.4 